\title{
原著
}

\section{部分床義歯の印象採得条件の違いが欠損部顎堤粘膜の 印象面形態に及ぼす影響について}

\author{
佐 藤 雅 之 \\ 東京医科歯科大学歯学部歯科補緅学第 1 講座（主任・指導：藍 稔教授)
}

(1995 年 12 月 8 日 受付)

\section{Influence of Various Impression Procedures for Mandibular Distal Extension Removable Partial Denture on Displacement of Residual Ridge}

\begin{abstract}
Masayuki Sato
The First Depertment of Prosthodentics, Faculty of Dentistry, Tokyo Medical and Dental University (Chief and Director : Prof. Minoru Ai)

In order to investigate the influence of various impression procedures on the morphology of the partially edentulous mucosal tissue precisely, a new 3-D measurement system based on a binocular-temporal gradient method was devised. The greatest advantage of the system is that the amounts of substance and minute deformation of the object can be easily measured simultaneously. The accuracy of the system is $0.1 \mathrm{~mm}$ and $10 \mathrm{~mm}$ in the substance measurement and in the deformation measurement respectively.

Three parameters selected for the impression procedure were the space between the inner surface of the tray and the mucosal tissue, the flow of impression material and the size of tray. It was found that the amount of displacement in the mucosal tissue was increased as the thickness of space on the tray was reduced or the viscosity of the impression material was increased in partially edentulous patients. Moreover, the large tray caused greater displacement around the margin than the small one.
\end{abstract}

\section{I. 緒言}

部分床義歯は歯および粘膜の両方に支持を求め ることが多いので，その製作に当たっては一般に 機能時における両者の被圧変位量の違いを考慮に 入れなければならない。欠損部顎堤粘膜は残存歯 に比べて被圧変位量が大きく，義歯負担時には安 静時とは形態が異なると考えられることから，印 象採得の際の欠損部顎堤粘膜に対する扱いが問題 になる ${ }^{1,2)}$ 。しかし実際に，印象採得における条件
の違いが印象面の形態にどのような影響をもたら すかに関しては，これまで種々研究が行われてき たにも関わらず未だ不明な点が多い。 その原因の一つに測定方法があげられるであろ う。すなわち, 従来の方法の多くは接触型の測定 装置を用いており，採得した印象面を直接測定し ようとすると接触により印象面を変形させ, 正確 な形状測定が困難であった。そのため，印象から 石膏模型を作り，そのうえで計測する方法も行わ れたが, その場合には, 印象から石膏に置き換之 
る際の寸法変形が誤差として含まれ，十分な精度 を得ることが困難であった。

また，印象条件を変えたときの粘膜の動態につ いては, シミュレーションモデルの印象について すでに多数の報告がなされている3 ${ }^{3 \sim 7}$ が, 実際の口 腔内で採得された印象についての報告は少な 〈 ${ }^{8 \sim 11)}$, 特に印象面形態の直接観察例は稀有であ る。

さきに当教室の耿 ${ }^{5)}$ は, 印象面の形態を直接測 定するための新たな非接触型計測システムを開発 した。このシステムでは異なる条件で採得した 2 つの印象面形態の違いを三次元的に高い精度で測 定可能である。しかし，この測定法では印象条件 の違いが相対変化量でのみ表されるために，その 結果からは対象となる印象面と条件の違いによる 微小変形の位置関係を正確に把握することが困難 であった。

今回この欠点を補うため, 測定対象物の実体つ まり印象面と，その微小変形量とを同時に測定で きるステレオ型時空間微分三次元計測システムを 開発した。本システムは基本的には，測定対象物 に明暗模様のパターンを投影する一軸移動機構と 2 台の汎用のテレビカメラから構成され，その投 影パターンの動きに対し微分型アルゴリズムを適 応して，テレビカメラに映る対象物の奥行き方向 の量を測定するものである。

本研究ではこのステレオ型時空間微分三次元計 測システムを用いて, 被験者の顎堤粘膜について 印象条件の違いがその印象面の形態にいかなる影 響を及ぼすか検討を行った。

\section{II. ステレオ型時空間微分三次元計測システム}

\section{1. 装置の構成}

本システムは, 対象物の三次元的な絶対量とこ の対象物の変形前後における三次元的な微小な形 態の違いを非接触方式で測定するものである。本 論文では前者を実体計測, 後者を微小変形計測と する。実体計測では左右のカメラの画像デー夕を もとにカメラに写る対象物の光軸方向の高さを測 定し, 一方微小変形計測では対象物の変形前, 後
の画像データをもとにカメラに写る対象物の光軸 方向の変位を測定する。この装置は耿ら ${ }^{5,12)}$ が用い た三次元微小変形測定装置を発展させたものであ ク，ランダムな縞模様を対象物に投影するための 2 台のプロジェクタ (COSMICAR 社製レンズ 25 mm 1 : 1.4), プロジェクタを固定する微動ス テージ駆動用のステッピングモーター（中央精機 社製 PS-120 EXY)，2 台の CCD カメラ(SONY 社製 XC-77)，そしてシステム制御用のコン ピュータ (Sun Microsystems 社製 SS-4) から構 成されている(図 1，2)。この装置では実体計測 と微小変形計測で異なる縞模様を用いるため, そ れぞれの縞模様を投影するために 2 台のプロジェ クタを配置した。

\section{2. 基本原理}

実体計測に関して, 対象物上の座標系を $(x, y$, z) とし, カメラ I の CCD 面上の座標系を $(X$, $Y)$, カメラ II の CCD 面上の座標系を $\left(X^{\prime}, Y^{\prime}\right)$ とする。図 3 に示すように左右カメラの距離を $D$, 基準面までの距離を $H$ とし $(D \ll H)$, カメ ラ I を対象物の正面に, カメラIIを中心よりずれ た位置に置く。カメラIに固定された $X Y$ 軸と対 象物の $x y$ 軸は平行とする。2 台の CCD カメラの

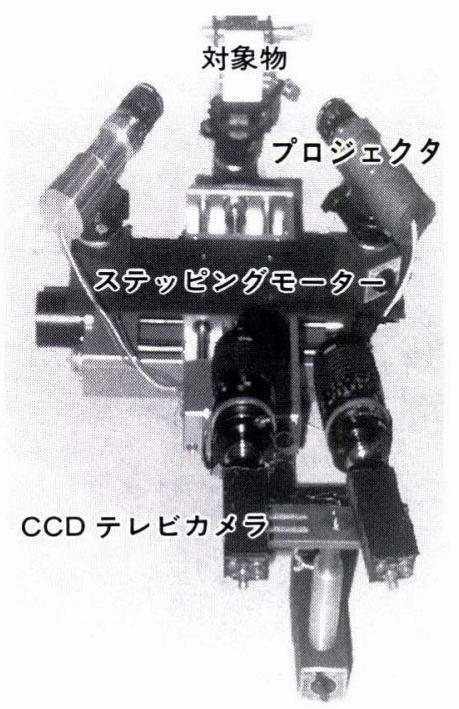

図 1 ステレオ型時空間微分三次 元計測システム 


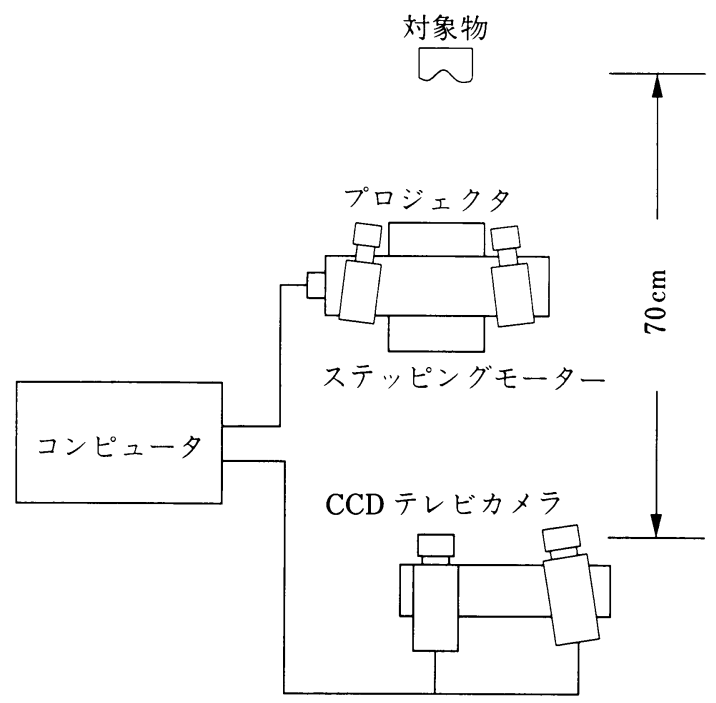

図 2 本システムのブロックダイヤグラム

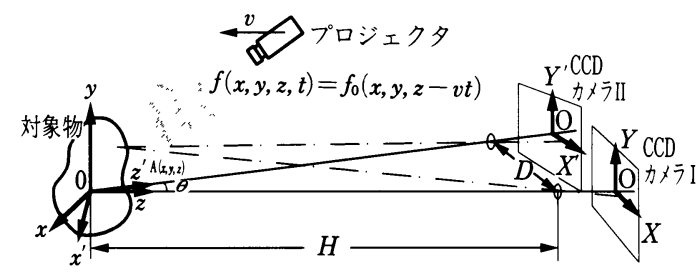

困 3 測定原理

なす角度を $\theta$ とし, 対象物のある 1 点 $\mathrm{A}(x, y$, z)について考えると，この点が投影されるカメラ I の CCD 面上の $X$ 座標， $Y$ 座標はそれぞれ

$\left(\begin{array}{c}X \\ Y\end{array}\right)=\frac{\alpha}{1-\frac{z}{H}}\left(\begin{array}{l}x \\ y\end{array}\right)$

と表せる ( $\alpha$ は定数)。同様にカメラ II CCD 面 上の $X^{\prime}$ 座標と $Y^{\prime}$ 座標はそれぞれ

$$
\left(\begin{array}{c}
X^{\prime} \\
Y^{\prime}
\end{array}\right)=\frac{\alpha}{1-\sqrt{H^{\prime}+D^{2}}}\left(\begin{array}{l}
x^{\prime} \\
y^{\prime}
\end{array}\right)
$$

と表せる。ここで $x^{\prime}, y^{\prime}, z^{\prime}$ を $x, y, z$ で表すと $y^{\prime}=y$

$\left(\begin{array}{l}x^{\prime} \\ y^{\prime}\end{array}\right)=\left(\begin{array}{ll}\cos \theta & \sin \theta \\ -\sin \theta & \cos \theta\end{array}\right)\left(\begin{array}{l}x \\ y\end{array}\right)$

と書け，(2)式は
$\left(\begin{array}{c}X^{\prime} \\ Y^{\prime}\end{array}\right)=\frac{\alpha}{1-\frac{(-x \sin \theta+z \cos \theta)}{\sqrt{H^{2}+D^{2}}}}\left(\begin{array}{c}x \sin \theta+z \cos \theta \\ y\end{array}\right)$

となる。 $H \ll x, z$ とすると(1)式と(3)式はそれぞれ

$X+\alpha x$

$X^{\prime} \cong \alpha \quad(x \sin \theta+z \cos \theta)$

と近似できる。さらに 2 台のカメラのなす角 $\theta$ が $\theta \ll 1$ とみなせるとき(4)式は

$\mathrm{X}^{\prime} \cong \alpha(x+z \sin \theta)$

となる。したがって(4)式と(6)式により $X, X^{\prime}$ と $z$ とは

$z=\frac{X^{\prime}-X}{\alpha \sin \theta}$

の関係で示される。よって同一の点が 2 台のカメ ラに投影されたときの投影位置の差の量 $X^{\prime}-X$ から $z$ が求められ, これが対象物のカメラの光軸 方向の高さとなる。

しかし，ここで 2 台のカメラの像を見比べたと き，一方の像内の点が他方のどの点に対応してい るかを判定するのは一般に困難とされている ${ }^{13)}$ そこで本システムではプロジェクタで縞模様を投 影し，それを動かしたときの複数枚の画像系列を 用いることにより，2台のカメラの像内の対応す る点を判別するようにしている。

いまランダムな縞模様を投影しながらそのプロ ジェクタが $z$ 軸に沿って速度 $v$ で移動したとき, 対象物上の光強度場は $f(x, y, z, t)=f_{0}(x, y$, $z-v t)$ と表せる。測定対象物である散乱表面 $S$ の 高さを $z=S(x, y)$ と表すと, カメラ I での光強 度の経時的変化 $F_{1}(X, Y, t)$ は

$F_{1}(X, Y, t)=\gamma_{1}(x, y) f_{0}(x, y, S(x, y)-v t)$

と表せ, 同様にカメラ II での光強度の経時的変化 $F_{2}(X, Y, t)$

$F_{2}\left(X^{\prime}, Y^{\prime}, t\right)=\gamma_{2}(x, y) f_{0}(x, y, S(x, y)-v t)$

と表せる。これらと(6)式の関係から, 左右のカメ ラの像の時系列は

$F_{2}\left(X^{\prime}, Y^{\prime}, t\right)=\frac{\gamma_{2}(x, y)}{\gamma_{1}(x, y)} F_{1}(X+\alpha z \sin \theta, Y, t)(10)$ なる関係で表される。 $\gamma_{1}, \gamma_{2}$ は対象物上の反射率お よび角度によって決まる関数である。いま対象物 上のある 1 点について注目し，その時系列をみる 
のであれば $\gamma_{1} / \gamma_{2}$ は定数であるから，カメラ I の 点 $(X, Y)$ の明るさの時系列はカメラ II の点 $(X-\alpha z \sin \theta, Y)$ における明るさの時系列の定 数倍である。それゆ之に投影パ夕ーンが不均一で 各点 $(X, Y)$ ごとに明るさの時系列が異なってい るのであれば，以下のようにカメラ I とカメラII の明るさの時系列の相関関係を求めればよい。こ のとき相関

$\alpha(d)=\frac{\left|\int F_{1}(X, Y) F_{2}(X-d, Y) d t\right|^{2}}{\int\left\{F_{1}(X, Y)\right\}^{2} d t \int\left\{F_{2}(X, Y)\right\}^{2} d t}$ (11) は $d=a z \sin \theta$ のとき最大となる。よって各 $(X$, $Y)$ ごとに(11)式の $\alpha(d)$ が最大となる $d$ を探索す れば，対応する点の高さ $z$ が求められる。

微小変形の測定原理については，すでに耿5)お よび篠田ら ${ }^{12)}$ が詳細に述べているが，実体計測と 同様に $z$ 軸に沿って速度 $v$ でプロジェクタが移 動して光強度 $f(x, y, z, t)=f_{0}(x, y, z-v t)$ を生 成するとする。変形前の対象物表面 $S_{1}$ を $z=S_{1}$ $(x, y)$ で表したとき, $z$ 軸上の CCD 面上での光強 度 $g_{1}(X, Y, t)$ は

$g_{1}(X, Y, t)=r_{1}(x, y) f_{0}\left(x, y, S_{1}(x, y)-v t\right)$ となる。ただし， $r_{1}$ は対象物上の反射率と角度に よって決まる関数である。次に, 全く同条件で変 形後の対象物表面 $S_{2}: z=S_{1}(x, y)+\Delta S(x, y)$ に 対して同様に $g_{2}(X, Y, t)$ を観察すると

$$
\begin{aligned}
\frac{g_{2}(X, Y, t)}{r_{2}(X, Y)} & =f_{0}\left(x, y, S_{1}(x, y)-v t\right) \\
& =\frac{g_{1}(X, Y, t-\alpha(X, Y))}{r_{1}(X, Y)}
\end{aligned}
$$

ただし

$\alpha(X, Y)=\frac{\Delta S(x, y)}{v}$

である。このように変形前の表面 $S_{1}$ と変形後の表 面 $S_{2}$ に対する動画像デー夕 $g_{1}, g_{2}$ を各画素ごとに 考えると, 一方の時系列デー夕はもう一方のデー タに対し， $\Delta S$ に比例した時間軸方向のシフトと 反射率で決まる強度方向への拡大を受けている。

ここでは各画素ごとに時間軸のシフト $\alpha(X, Y)$ を推定することにより, 対象物の微小変形量 $\Delta S$ $(x, y)$ を(14)式から決定している。

本測定ではプロジェクタの1ステップあたりの
移動量を実体計測では $1.0 \mathrm{~mm}$, 微小変形計測で は $200 \mu \mathrm{m}$ とし，40ステップ移動した。1ステッ プ移動するごとにC C D カメラで対象物の像を 1 枚撮影し，全ステップ分の画像をコンピュータに 取り込んだ。微小変形計測の場合にはこの過程を 変形前と変形後の対象物に対して行い, これらの 画像デー夕をもとに対象物の微小変形量の最良推 定値を算出した。ここで得られる微小変形量とは 変形後の対象物を基準に変形前の対象物をみたも のであり，得られたデー夕が正の時は変形前の対 象物が変形後の対象物よりカメラ I の方向でカメ ラ寄りにあることを示している。また実体量につ いては変形前の実体量を計測し, 変形後の実体に ついては微小変形計測で得られた差分デー夕を変 形前のデータに加算することによって得ている。 画像データの 1 画素の大きさは縦横 $80 \mu \mathrm{m}$ であ る。

\section{III. 測定装置の精度評価のための基礎的実験}

本システムは微小変形量と実体量を同一の装置 で，高い分解能と精度を維持しながら測定できる ことが原理的な特徵であるが，実際的に測定する うえでの精度を確かめるために以下の実験を行っ た。

\section{1. 実体計測}

1) 実験方法

本システムを用いて実体計測を行った際の測定 精度を評価するために，既知の大きさの立体を測 定した。測定対象物はマイクロメータ付きステー ジ上に固定した 2 枚の白色のアクリル板である

(図 4 )。この装置は一方のアクリル樹脂が CCD カメラの光軸方向に移動し， 2 枚の間に一定の段 差が生じるようになっている。アクリル板の移動 量は $0 ， 1 ， 2 ， 5 ， 10 \mathrm{~mm}$ である。測定領域は $4.0 \times 4.0 \mathrm{~mm}(50 \times 50$ 個の測定点 $)$ である。それ ぞれの移動量について 3 回測定を行い, その值を 平均した。

\section{2 ) 結果}

図 5 は $5 \mathrm{~mm}$ の移動に対する測定結果である。 $4.95 \mathrm{~mm}$ を中心 $00.1 \mathrm{~mm}$ の範囲でデータが 

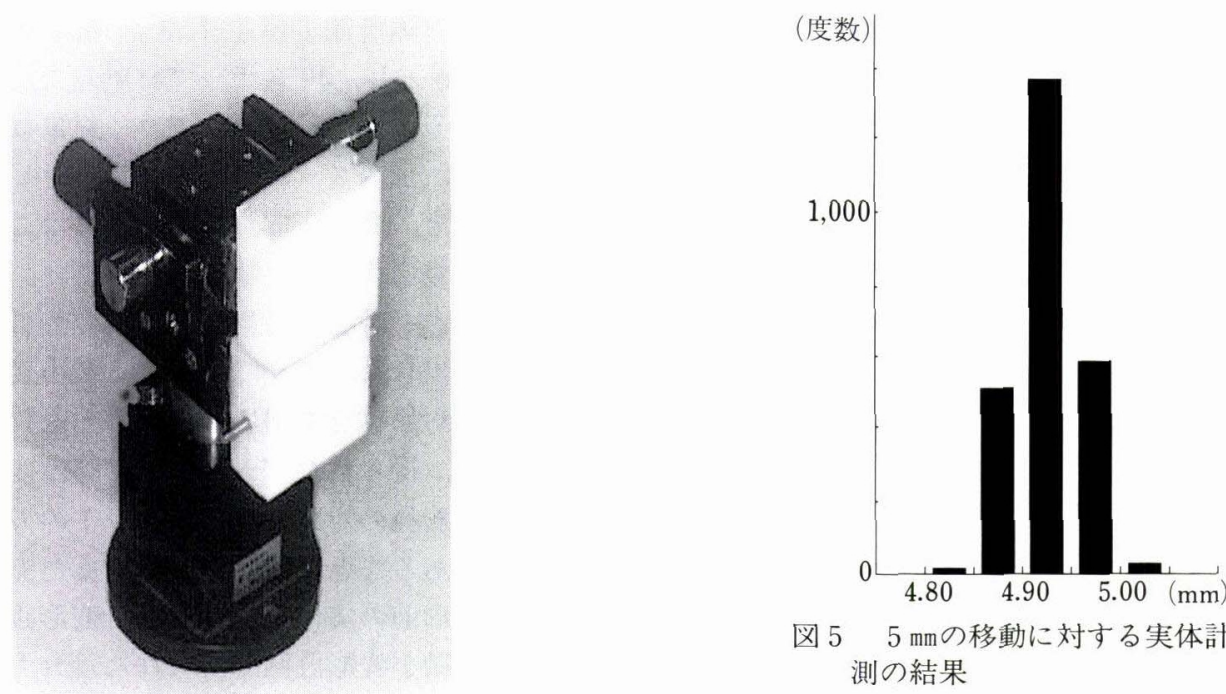

図 $55 \mathrm{~mm}$ の移動に対する実体計 測の結果

困 4 既知の移動量を与えられる 測定対象物

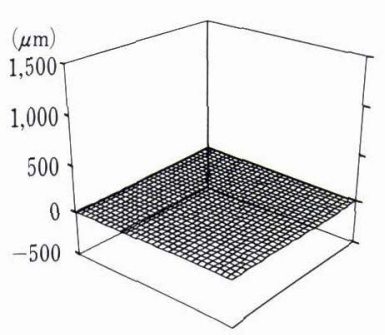

(a)

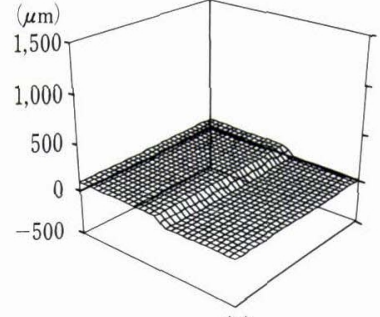

(b)

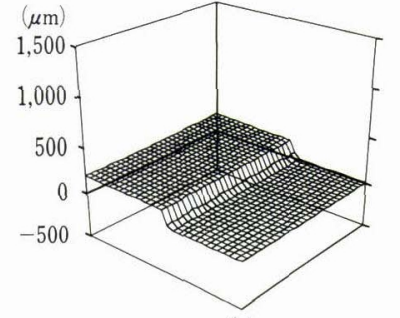

(c)

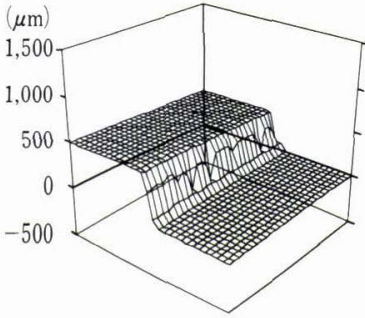

(d)

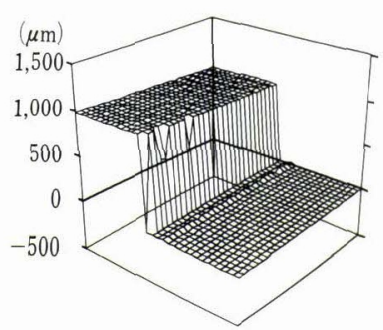

(e)

図 6 既知の微小変形の計測の際の三次元透視困

$\mathrm{a}: 0 \mu \mathrm{m}, \mathrm{b}: 100 \mu \mathrm{m}, \mathrm{c}: 200 \mu \mathrm{m}, \mathrm{d}: 500 \mu \mathrm{m}, \mathrm{e}: 1,000 \mu \mathrm{m}$

分布した。他の移動量に関しても同様の分布が得 られた。

\section{2. 微小変形計測}

1) 実験方法

本システムの微小変形計測の測定精度を評価す
るために, 既知の微小変形の付与が可能な対象物 を測定した。使用した対象物は実体計測に使用し たものと同じである。本実験で付与した微小変形 量は， 0，100，200，500，1,000 $\mu \mathrm{m}$ である。コ ンピュータによる処理の際に縦横 2 画素ずつ合計 
4 画素を測定点とした。測定領域は $7.2 \times 7.2 \mathrm{~mm}$ $(30 \times 30$ 個の測定点) である。それぞれの移動量 について 3 回ずつ測定を行い, それぞれの測定点 について平均值を求めた。

\section{2 ) 結果}

図 6 は 900 個の測定点から得られた微小変形の 三次元透視図である。各図ともそれぞれの微小変 形量を忠実に再現していることが確認できる。ま た困 7 は微小変形量を $200 \mu \mathrm{m}$ としたときの変形 部分の測定結果である。付与した微小変形量の $200 \mu \mathrm{m}$ を中心に $10 \mu \mathrm{m}$ の範囲にデータが分布 した。他の微小変形量についても同様の結果が得 られた。

以上より本システムでは測定が $1 \mathrm{~mm}$ の範囲 であれば，その変形量を $\pm 10 \mu \mathrm{m}$ の範囲で測定が 可能といえる。

3. 自由変形をする物体の計測 (実体計測と微小变 形計測の併用例)

\section{1 ) 実験方法}

欠損部顎堤粘膜の印象時の変形量は既知ではな く，また均一に変形するとは限らない。そのため 自由変形をする対象物について, 実体計測と微小
変形計測の両者を用いて測定し精度検定を行っ た。対象物は図 8 にあるように白色のアクリル板 に直径 $40 \mathrm{~mm}$ のゴム製の球面を接着したもので ある。これは球面の裏側中央にワイヤーの一端が, そしてマイクロメータにワイヤーの他端が固定さ れている。マイクロメータがこのワイヤーを引く とゴム製の球面が変形するようになっている。今 回の実験では,ワイヤ一の引く量を $0.5,1.0,1.5$, $2.0 \mathrm{~mm}$ と規定した。

2 ) 結果

図 9 は実体計測と微小変形計測より得られた デー夕をもとに描いた三次元透視図である。微小 変形計測の三次元透視図についてみると, ワイ ヤーによって引かれた量に応じて三次元透視四の 中央付近を最大とした凸状にみえる正の変形，つ まりカメラと反対方向の変形をしていることがわ かる。一方, 変形前後の実体計測の結果をみると, ワイヤーによって引かれた量に応じて球面の中央 付近を最大として凹状に変形を起こしていること がわかった。

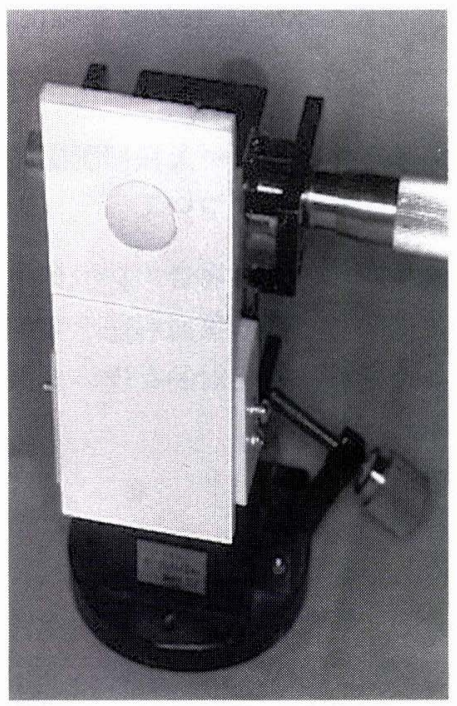

困 8 自由変形を起こすことが可 能な測定対象物

図 $7200 \mu \mathrm{m}$ の微小変形計測の測定結果 

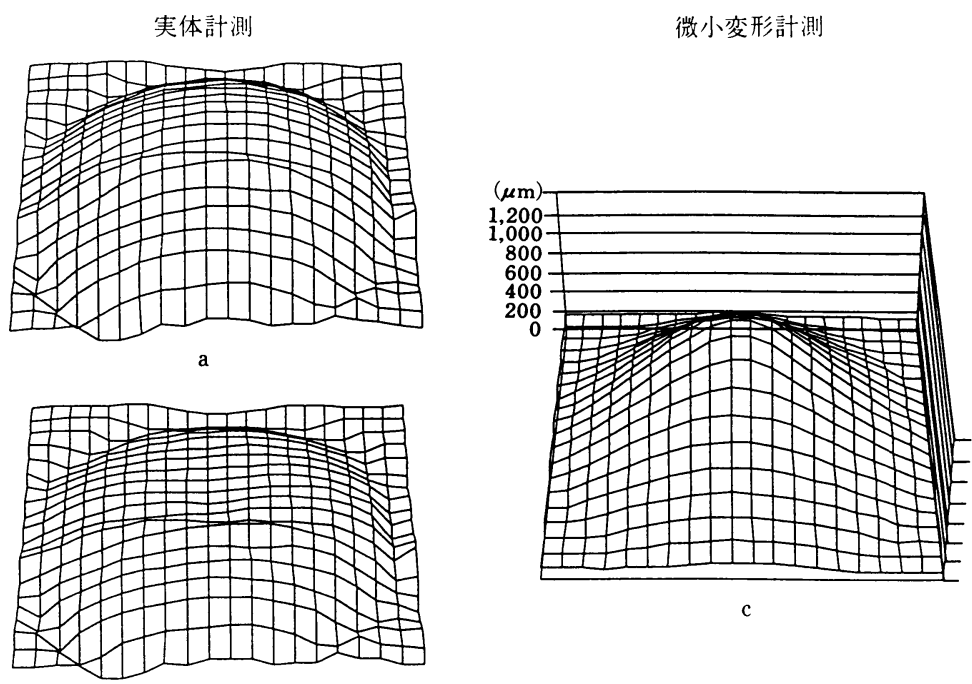

b

図 9 自由変形をする物体の測定結果

$\mathrm{a}$ ：変形前の実体, $\mathrm{b}$ ：変形後の実体, $\mathrm{c}$ ：微小変形

表 1 被験者

\begin{tabular}{c|c|c|c|c}
\hline \hline 被験者 & 年龄 & 性別 & 欠損部位 & 印像採得部位 \\
\hline $\mathrm{A}$ & 60 & $\mathrm{~F}$ & $\sqrt{67}$ & $\sqrt{67}$ \\
\hline $\mathrm{B}$ & 54 & $\mathrm{~F}$ & $\overline{7-5}$ & $\overline{7-5}$ \\
\hline $\mathrm{C}$ & 55 & $\mathrm{~F}$ & $\overline{7-5} \mid 4-7$ & $\overline{4-7}$ \\
\hline $\mathrm{D}$ & 61 & $\mathrm{M}$ & $\overline{7-5} \mid 67$ & $\overline{7-5}$ \\
\hline
\end{tabular}

\section{IV. 印象採得条件の違いが欠損部䫓堤粘膜の印象 面形態に及ぼす影響について}

印象条件を変化させた場合の顎堤粘膜の形状に ついて，各条件ごとの印象面形態を実体計測し， さらに各条件間のその相対的な違いを微小変形計 測により検討した。

\section{1. 方法}

\section{1) 被験者}

被験者は，下顎臼歯部に歯牙欠損を有する義歯 装着経験者で，顎口腔系になんら機能異常が認め られない男性 1 名および女性 3 名の計 4 名 (54 61 歳, 平均 57.5 歳) である（表 1 )。

2 ) 計測準備

\section{（1）作業用模型}

それぞれの被験者にアルジネート印象材により 下顎残存歯列および欠損部顎堤の印象採得を行っ た後，研究用模型を製作し，その模型上で機能印 象用個人トレーを製作した。トレーは常温重合型 トレー用レジン (GC 社製オストロン II) を用いて 製作したが，残存歯部にパラフィンワックス (GC 社製 BASE PLATE PARAFFIN WAX) 1 枚分 のスペーサを置き，久損部にはスペーサを置かな かった。この個人トレーを用いて被験者の口腔内 で可動粘膜に相当する印象辺縁部分に対してモデ リングコンパウンド (Kerr 社製 Impression Compound)により筋圧形成を行った後，ポリサルファ イドラバー印象材（GC 社製シュールフレックス Fレギュラー)で印象採得した。この印象にただち に超硬石高（GC 社製ニューフジロック）を注入 し，作業用模型を製作した。

(2) 口腔内装置

完成した作業用模型上で以下の口腔内装置を製 作した。

(a) トレー扱入規定装置

図 10 は実験用トレーを口腔内の定位置に抻入 するためのトレー挿入規定装置で，被験者の下顎 


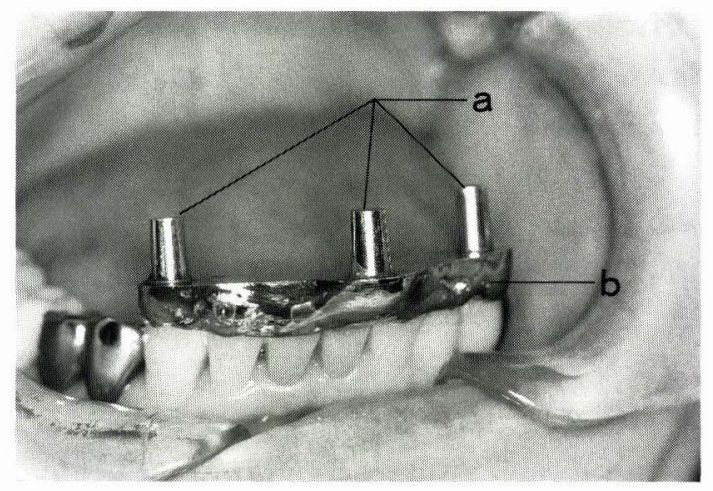

図 10 トレー挿入規定装置

$\mathrm{a} ：$ ガイドレール, b：前歯被覆部

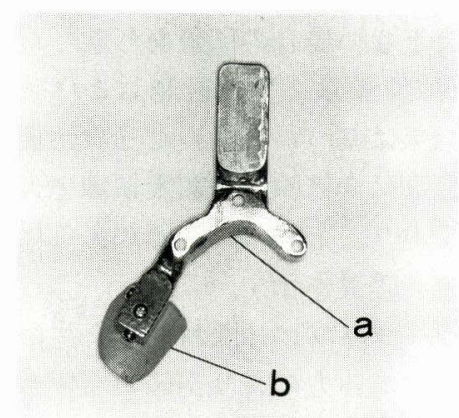

困 11 粘膜面印象用卜レー $\mathrm{a} ：$ 金属部, $\mathrm{b} ：$ レンジ部. $\mathrm{b}$ は可撤 式になっており，aと衫じで固定 されている

前歯を被覆する形状とし，Co-Cr 合金（三金工業 社製サンコリウム）で製作した。この前歯被覆部 分の上面は実験用トレーを支えるため, トレー㨂 入方向に垂直な平面とし，また挿入方向を規定す るためにこの面に 3 本のガイドレールが植立され ている。この装置を仮着用セメント（松風社製ハ イボンドテンポラリーセメント硬性）で歯列に固 定した。

(b) 粘膜面印象用トレー

困 11 は粘膜面印象用トレーで,レジン部と金属 部で構成されている。

レジン部は作業用模型上の欠損部分に常温重合 型トレー用レジン（GC 社製オストロン II）を圧接 して製作したが，欠損部の粘膜の加圧条件を変え
るために形態の異なる 3 種類を製作した。つまり， 粘膜面と印象面との間に空隙がないもの，空隙が あるもの，そして床縁の短いものの 3 種類である。 空隙があるものは，作業用模型上に厚さ $1.4 \mathrm{~mm}$ のパラフィンワックス ( $\mathrm{GC}$ 社製) をスペーサとし て置き空吵量を規定した。辺縁の短いものは，空 隙を設けずに辺縁の位置を $3 \mathrm{~mm}$ 内側に設定し た。

一方，金属部は $\mathrm{Co}^{-} \mathrm{Cr}$ 合金 (三金工業社製サン コリウム）で製作し，実験用トレーが定位置に㨂 入できるよう上記のトレー挿入規定装置と適合さ せるものである。レジン部と金属部の連結部分は コンポジットレジン（クラレ社製クリアフィル F IIニューボンド）で製作し，ねじにより強固に連 結した。

(c) トレ一保持装置

印象採得時の印象保持圧を規定するため, 卜 レ一保持装置を製作した。図 12 は口腔内にこれを 装着した状態である。保持装置上部と下顎下縁を 手指で挾みトレーを保持するような構造とした。 トレ一上部と接触する部分にはロードセル $(\mathrm{ST}$ 研究所製 LM 6-5）を設置し，保持圧を導出した。

3 ) 測定方法

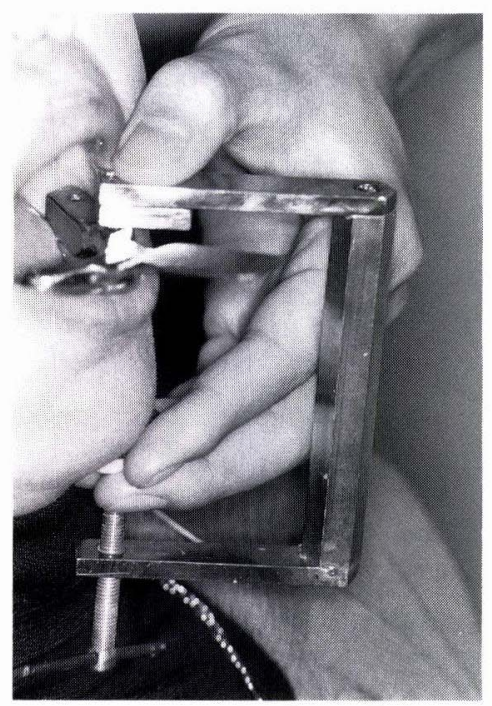

図 12 トレー保持装置 
(1) 印象材

本実験で使用した印象材はポリサルファイドラ バー印象材のレギュラータイプとインジェクショ ンタイプ ( $\mathrm{GC}$ 社製シュールフレックス $\mathrm{F})$ の 2 種 類である。

(2) 印象採得方法

通法に従い印象材を 45 秒間練和し，30 秒間で 印象用トレーに注入した。口腔内扱入の際には印 象用トレーを挿入規定装置のガイドレール上に置 き，手指により可及的に一定の速度になるように 挿入した。扱入圧接に要した時間は約 3 秒である。 印象用トレーが口腔内で定位置に納まった後, 保 持装置と手指により犬歯部で保持圧が $1 \mathrm{kgf}$ とな るようモニタリングしながらトレーを保持した。 口腔内で 10 分間保持した後印象を撤去した。

(3) 形状計測

口腔内で採得された印象を清掃後，ステレオ型 時空間微分三次元計測システムにより印象面を直 接測定した。形状計測の際に測定範囲が一定にな るようにジグ（図 13）を製作し，印象用トレーを

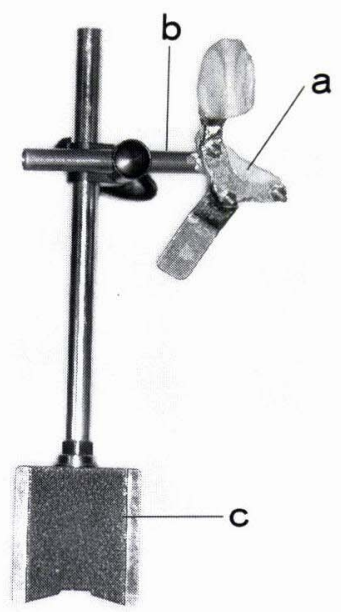

図13トレー固定用ジグ $\mathrm{a} ：$ 粘膜面印象用トレー, b : トレー 固定部, $\mathrm{c}$ ：台座. bに $\mathrm{a}$ をねじで固 定できるようになっている。cは図 1 の対象物の位置に固定される
これに固定した。測定範囲は印象用トレーの全範 冊が可及的に含まれるように設定した。測定点の 1 単位は縦横 $0.8 \mathrm{~mm}$ の正方形とした。

本研究における形状計測の検討対象としては以 下の 3 項目である。

1. 印象材のフローが一定でトレーに空隙があ る場合とない場合

2. トレーの空隙の条件が一定で印象材のフ ローを変えた場合

3. 印象材のフローとトレーの空陌の条件が一 定で，トレーの大きさを変えた場合

\section{2. 測定結果}

1) 印象材のフローが一定でトレーに空隙があ る場合とない場合の印象面形態

図 14 は被験者 D の実体計測および微小変形計 測の測定結果に基づいて描いた三次元透視困であ る。また図 15 は全被験者の測定領域中央部の煩舌 的断面図であり，トレーに空隙がある場合とない 場合の形態の差異を示す。

レギュラータイプの印象材の場合, 全被験者に おいて空吵のあるものより空吵のないもののほう が全体的に粘膜が変位する結果となった。部位別 にみると，実体の断面図（図 15）からわかるよう に頓側の粘膜では辺縁付近のほうが顎堤頂粘膜よ り変位の差が大きく, どの被験者も顎堤の形態が 凸から凹に変化する点すなわち変曲点付近から変 位が急に大きくなる傾向がみられた。その量は顎 堤頂付近から頓側の変曲点付近までは約 200 300 $\mu \mathrm{m}$ の範囲であったが, 変曲点付近より トレーの辺縁に近づくと最大で $800 \sim 1,000 \mu \mathrm{m}$ の範囲になった。舌側の粘膜は, 空隙のあるもの より空隙のないもののほうが変位が大きく現れる 傾向があったが, その量や部位について特徵的な 傾向はみられなかった。

インジェクションタイプの印象材の場合, 顎堤 頂付近から頓側の変曲点までの変位量はレギュ ラータイプと同様の傾向であったが, 変曲点から トレ一辺縁までの範囲では, レギュラータイプよ りも大きく変位していた。舌側については逆にレ ギュラータイプを用いたときのほうが大きく変位 

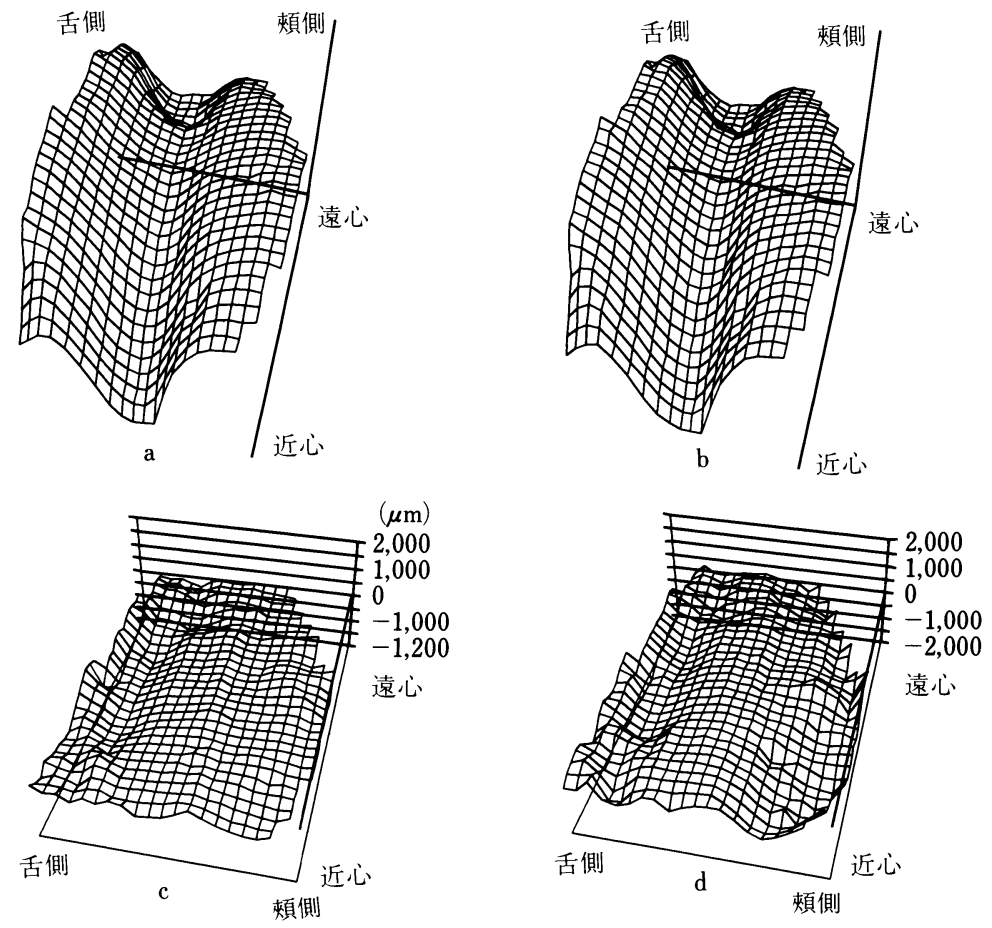

図 14 トレーの空隙のある場合とない場合を比較したときの三次元透視図 (被験者 D)

$\mathrm{a}$ ：笁吵のあるトレーの印象面, b：空隙のないトレーの印象面, $\mathrm{c} ：$ レ ギュラータイプのときの微小変形, $\mathrm{d}$ : インジェクションタイプのとき の微小変形

していた。

2）トレーの空隙の条件が一定で印象材のフ ローを変えた場合の印象面形態

図 16 は被験者 $\mathrm{A} の$ 実体計測および微小変形計 測の測定結果に基づいて描いた三次元透視困であ る。また図 17 は全被験者の測定領域中央部の煩舌 的断面図であり，レギュラータイプを用いたとき とインジェクションタイプを用いたときの形態の 差異を示す。

空陌のないトレーを用いた場合には，煩側では 全被験者とも辺縁付近においてレギュラータイプ のほうがインジェクションタイプより約 300 500 $\mu \mathrm{m}$ の範囲で変位が大きく現れた。顎堤 頂部では被験者 $\mathrm{A}, \mathrm{B}, \mathrm{C}$ でレギュラータイプより インジェクションタイプのほうが変位が大きく現
れ，被験者 Dではインジェクションタイプよりレ ギュラータイプのほうが変位が大きく現れたが, その量は $100 \mu \mathrm{m}$ 以下であった。舌側では, 辺縁付 近でインジェクションタイプよりレギュラータイ プのほうが変位が大きく現れる傾向があったが, その量や部位には特徵的な傾向はみられなかっ た。

印象用トレーに空隙がある場合には，全被験者 で煩側では辺縁付近で最も大きく変位し，特にレ ギュラータイプのほうが大きく変位していた。そ の量は被験者 $\mathrm{A}$ では約 $660 \mu \mathrm{m}$, 被験者 $\mathrm{B}, \mathrm{C}$ では 約 $250 \mu \mathrm{m}$, 被験者 D では約 $980 \mu \mathrm{m}$ となった。顎 堤頂部付近では被験者 $\mathrm{B}, \mathrm{C}, \mathrm{D}$ でレギュラータイ プよりインジェクションタイプのほうが変位が大 きく現れ，その量は $100 \mu \mathrm{m}$ 前後だった。また舌側 

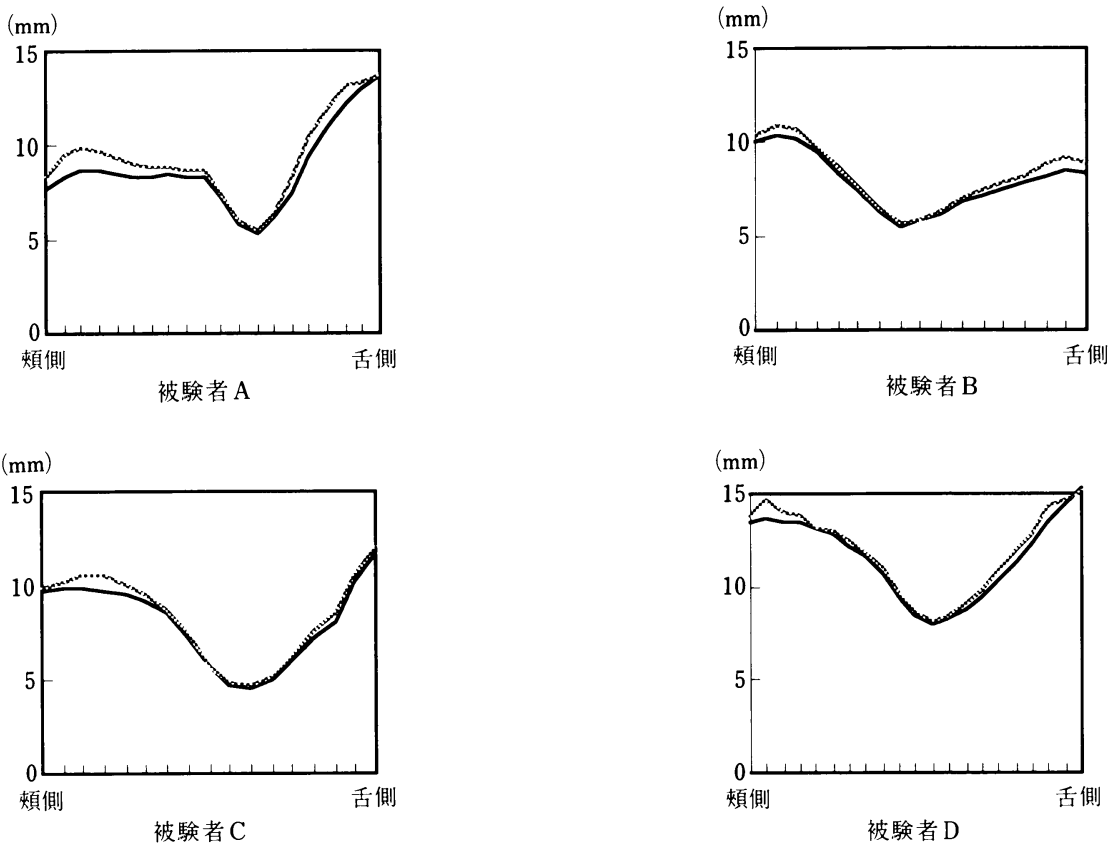

困 $15 \mathrm{a}$ 空隙がある場合とない場合を比較したときの頓舌的断面 使用した印象材はレギュラータイプ, 実線：空隙あり, 破線：空隌なし
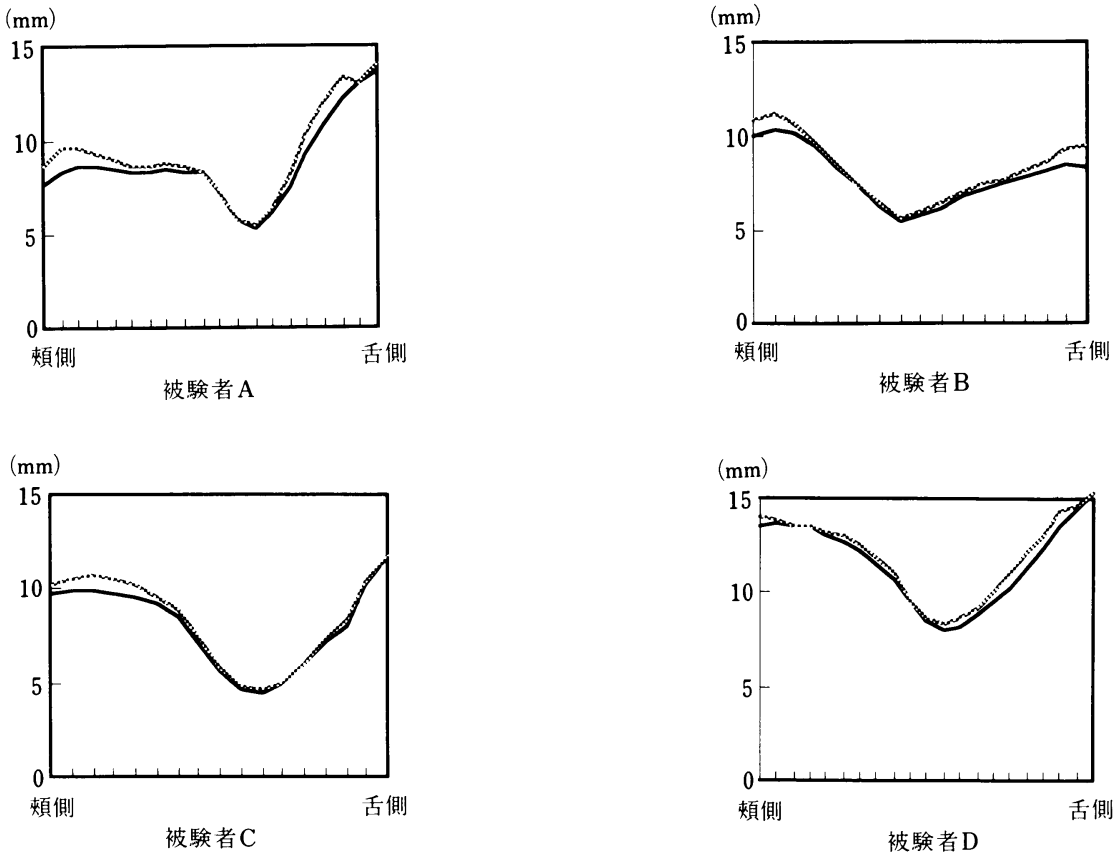

図 $15 \mathrm{~b}$ 空隙がある場合とない場合を比較したときの煩舌的断面 使用した印象材はインジェクションタイプ，実線：空跡あり，破線：空隙なし 


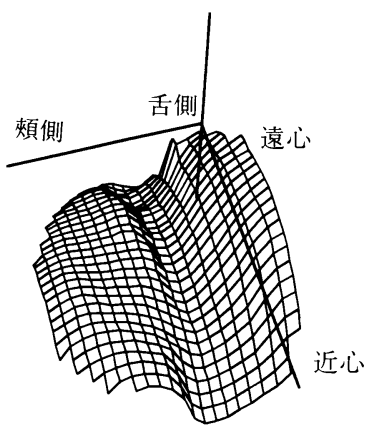

a

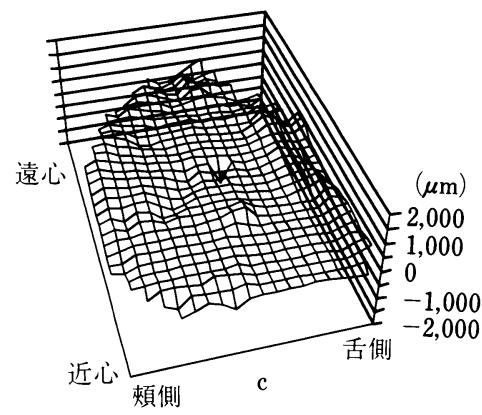

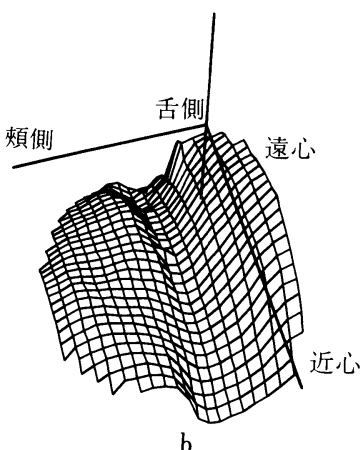

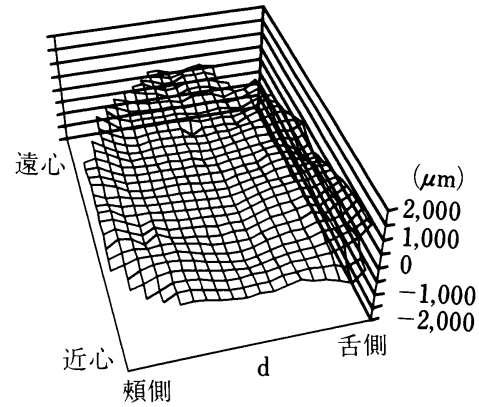

図 16 印象材のフローを変化させたときの三次元透視図（被験者 A) $\mathrm{a} ：$ レギュラータイプの場合の印象面, b：インジェクションタイプの場合 の印象面, $\mathrm{c}$ ：空隙のあるトレーの場合の微小変形, $\mathrm{d}$ ：空隙のないトレーの 場合の微小変形

では辺縁付近でレギュラータイプのほうがイン ジェクションタイプより粘膜は大きく変位してい た。また被験者 B, Cについては煩側辺縁付近の変 位量より舌側辺縁付近の変位量のほうが大きかっ た。

3 ) 印象材のフローとトレーの空吵の条件が一 定でトレーの大きさを変化させた場合の印象 面形態

図 18 は被験者 Cの実体計測および微小変形計 測の測定結果に基づいて描いた三次元透視図であ る。また図 19 は全被験者の測定領域中央部の煩舌 的断面図であり，辺縁の長いトレーを用いたとき と短いトレーを用いたときの印象面の形態の差異 を示す。

レギュラータイプを用いたときには被験者 $\mathrm{A}, \mathrm{B}, \mathrm{C}$ では辺縁の短いトレーより辺縁の長いト レーを用いた場合のほうが粘膜は全体的に変位し
ており，その傾向は顎堤頂部付近を最小に辺縁部 に向かって大きくなった。顎堤頂付近から煩側斜 面では辺縁の長いトレーのほうが $100 \mu \mathrm{m}$ 程度大 きく変位しており, 煩側辺縁では辺縁の長い卜 レ一のほうが $1,000 \mu \mathrm{m}$ 程度と大きく変位した。 被験者 Dについては，顎堤頂部付近で辺縁の短い トレーのほうが長いトレーを用いた場合より 300 $\mu \mathrm{m}$ 前後粘膜は大きく変位していたが，辺縁付近 では辺縁の長いトレーのほうが短いトレーの場合 より約 $1,000 \mu \mathrm{m}$ 程度大きく変位していた。

インジェクションタイプを用いたときには，被 験者 $\mathrm{A}, \mathrm{B}, \mathrm{D}$ で顎堤頂部付近の狭い範囲で辺縁の 短いトレーのほうが辺縁の長いトレーの場合より も大きく変位しているものの，それ以外の部位で は辺縁の長いトレーの場合のほうが短いトレーよ り $1,000 \mu \mathrm{m}$ 前後大きく変位していた。被験者 C では辺縁の短いトレーより辺縁の長いトレーを用 

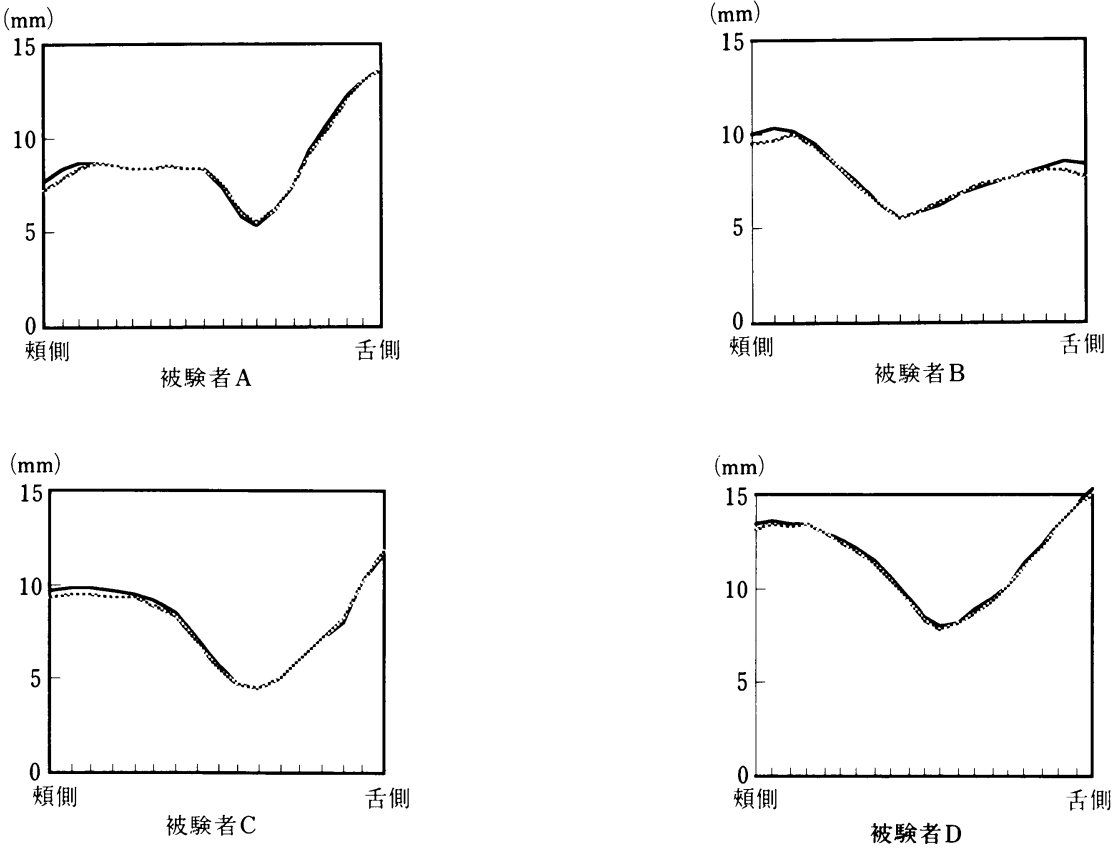

図 $17 \mathrm{a}$ 印象材のフローを変化させたときの頰舌的断面

使用したトレーは空陌のないもの。実線：レギュラータイプ, 破線：インジェクションタイプ

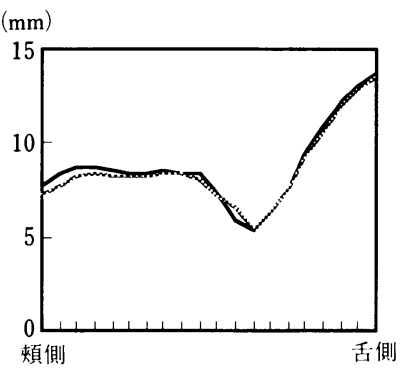

被験者 A

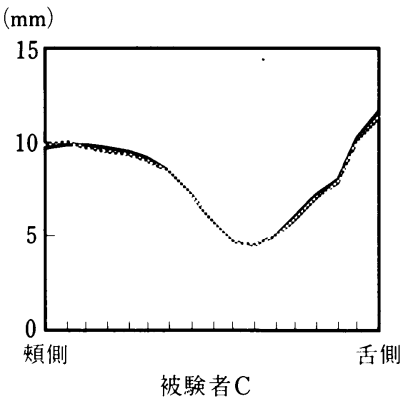

$(\mathrm{mm})$

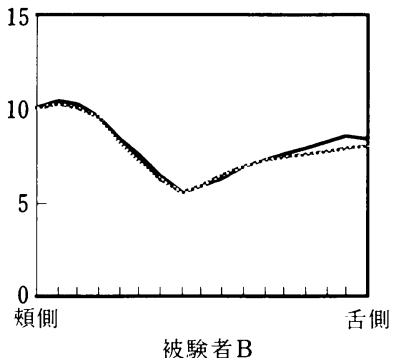

被験者 B

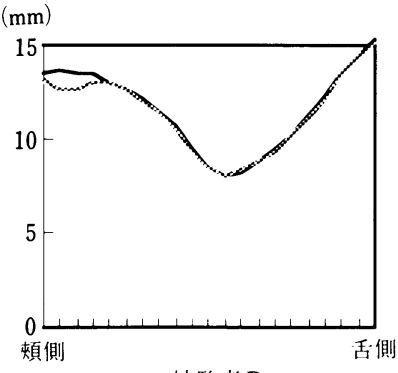

被験者 D

図 $17 \mathrm{~b}$ 印象材のフローを変化させたときの煩舌的断面図

使用したトレーは空隙のあるもの。実線：レギュラータイプ，破線：インジェクションタイプ 

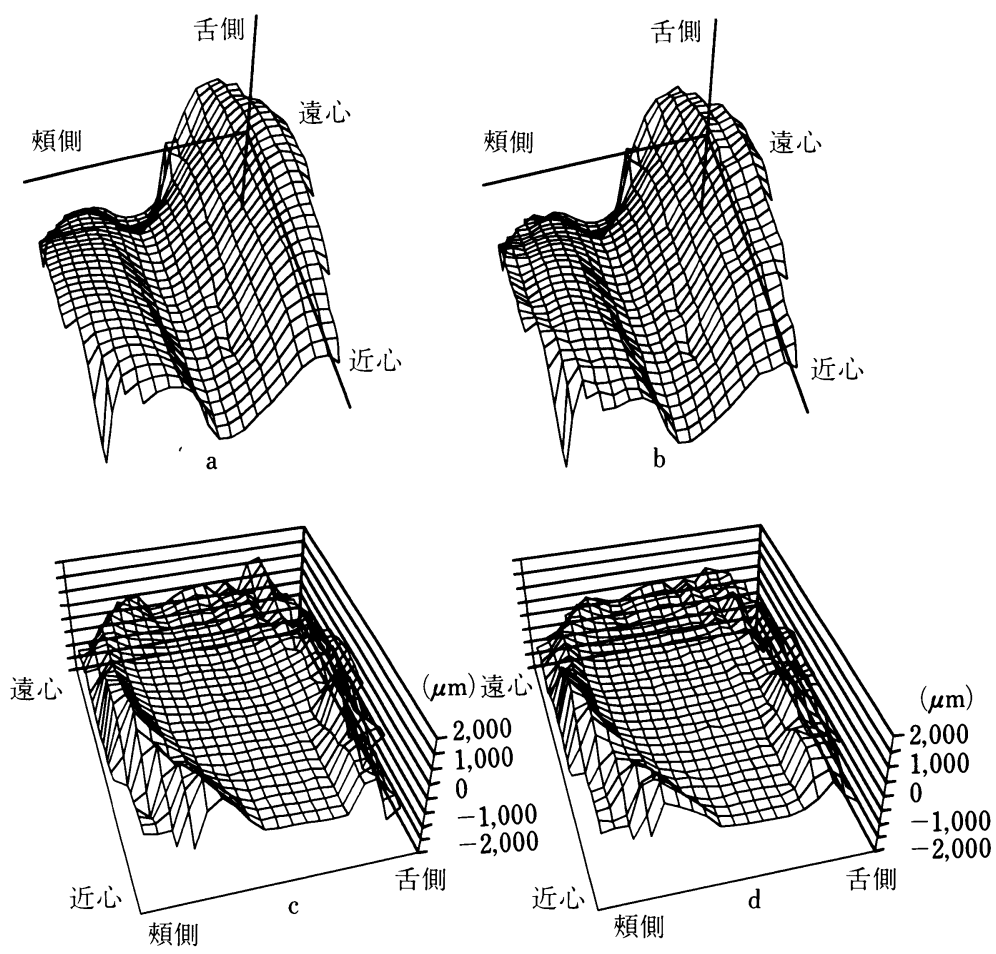

図 18 トレーの大きさを変化させたときの三次元透視困（被験者 C） $\mathrm{a}$ ：大きいトレーの場合の印象面, b：小さいトレーの場合の印象面, c : レ ギュラータイプの場合の微小変形, $\mathrm{d}$ ：インジェクションタイプの場合の微 小変形

いたほうが全体的に変位が大きく，その傾向は顎 堤頂部付近を最小に辺縁部に向かって大きく変位 していた。辺縁部では, 辺縁の長いトレーのほう が短いトレーを用いた場合より $1,300 \mu \mathrm{m}$ 程度大 きく変位していた。

全被験者にみられた煩側辺縁付近における辺縁 の長いトレーによる粘膜の変位については, 実体 の断面からわかるように顎堤の形状の変曲点を境 に顎堤頂側より辺縁側の方が変化の程度が大き かった。

\section{V. 考察}

遊離端義歯に代表される歯根膜粘膜負担性の部 分床義歯を製作する際には, 荷重時における歯と 粘膜の変位量の違いを考慮に入れなければならな い。歯と粘膜の両者ともに解剖学的形態を再現し
た印象から製作された義歯では，支台歯への負担 が過剩となり支台歯への悪影響が考えられる。そ こで粘膜面の印象に対して義歯の機能状態を再現 することにより支台歯への過剩な負担を回避し， 義歯として十分な機能を発揮できるようにするこ とが重要である。つまり粘膜部に対しては機能状 態の印象，すなわち機能印象を行わなければなら ない。従来より機能印象の有用性については種々 検討されている ${ }^{3,8 \sim 11,19 \sim 22)}$ 。Watt ${ }^{19)}$ は下顎遊離端 義歯を 1 週間装着した後の顎堤の形態は, 加圧印 象より得られた顎堤粘膜の形態に近似していたと 報告している。Leupold ${ }^{20,21)}$ は既製トレーによるア ルジネート印象とアルタードキャスト法により製 作した義歯の垂直的変位量を測定して, 後者の方 法で製作した義歯の方が沈下量が少なかったと報 告している。また, Matsumoto ${ }^{3}$ は下顎臼歯欠損の 

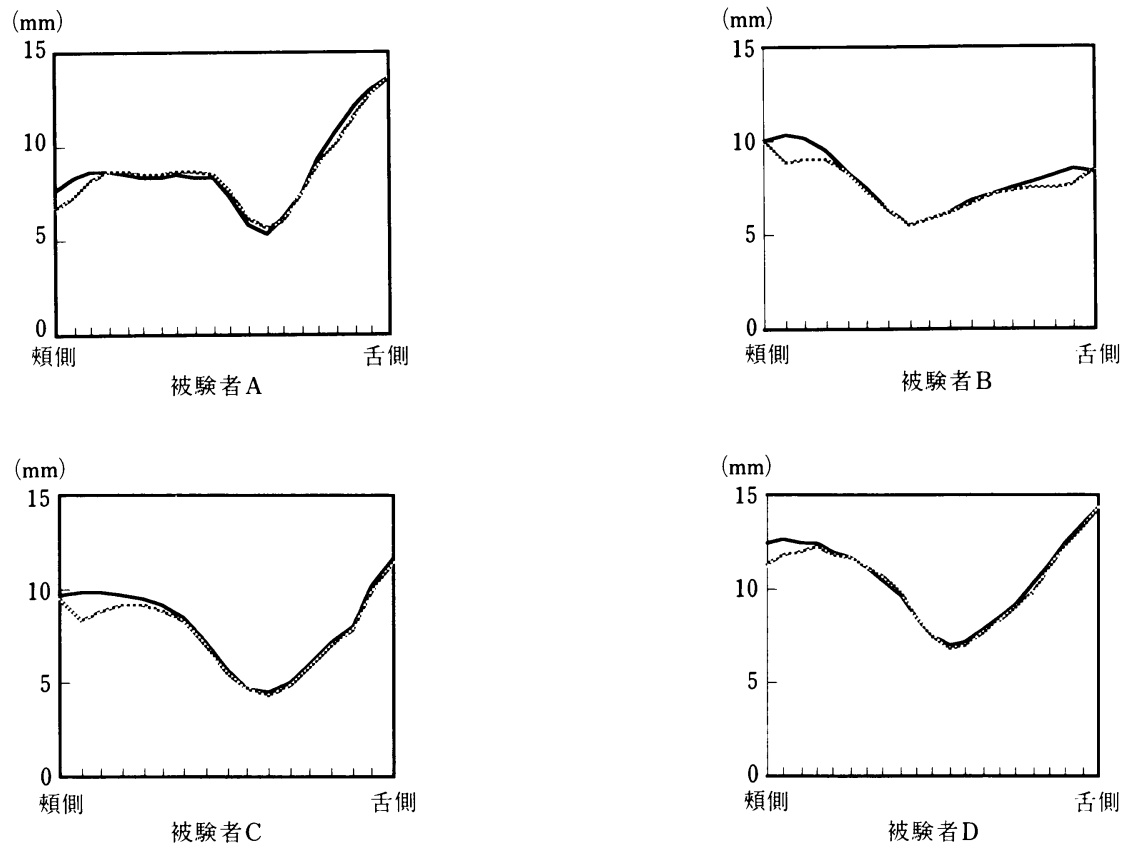

図 $19 \mathrm{a}$ トレーの大きさを変えたときの煩舌的断面

使用した印象材はレギュラータイプ。実線：大きいトレー，破線：小さいトレー

(mm)

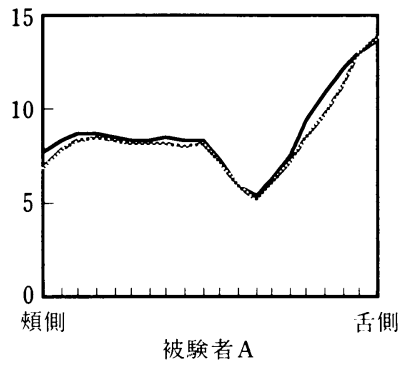

(mm)

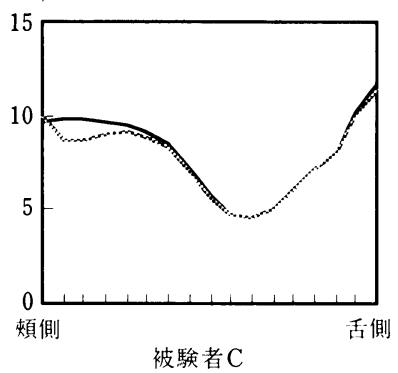

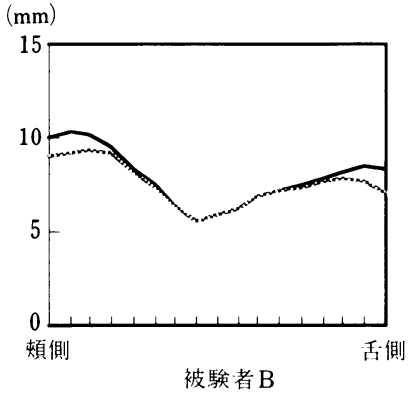

$(\mathrm{mm})$

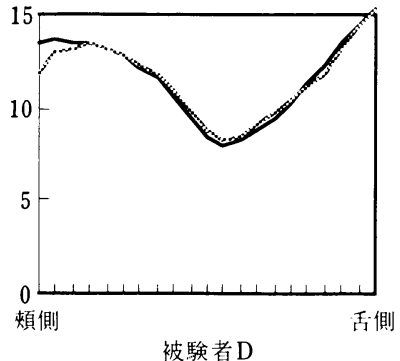

困 $19 \mathrm{~b}$ トレーの大きさを変えたときの頓舌的断面

使用した印象材はインジェクションタイプ. 実線：大きいトレー，破線：小さいトレー 
シミュレーションモデル上でレジン製個人トレー を用いたラバー印象を行った際, 顎堤粘膜の変形 量は義歯の沈下量とほぼ近似していたと報告して いる。さらに古宇田 ${ }^{8}$ は, 加圧印象と無圧印象が義 歯の適合性に対する影響を検討し，加圧印象によ る義歯のほjが適合性がよかったと述べている。

このように，部分床義歯を製作するうえで機能 印象法の重要性が強調されているが，それに伴う 粘膜の動態については未だ十分に解明されている とはいい難い。これは，印象採得の際の印象材の 性状, トレーと粘膜との間隔, トレーの圧接速度, トレーの保持圧などが粘膜の変形に複雑に関係す るためと考えられる。本研究では，新たに開発し たステレオ型時空間微分三次元計測システムを用 い，弾性印象材の印象面を非接触方式で直接測定 することにより，印象採得時の粘膜面の動態を明 らかにすることを目的として実験を行った。

\section{1. 研究方法}

1）ステレオ型時空間微分三次元計測システム

(1) 本システムの特徵

三次元形状の測定法は大きく接触計測と非接触 計測に大別できる。従来より印象面の測定にはそ の簡便さから接触計測法が多く用いられてきた が，直接測定では印象面が変形する恐れがあり， また石膏模型に置き換えたうえでの測定では石高 硬化時の寸法変化や測定針の接触時の滑りなどに よって正確な形状計測が容易ではなかった。耿 $ら^{5,12)}$ は非接触計測法としての三次元微小変形測 定装置を開発し，これによる印象面の測定を行っ た。この装置は印象条件の違いによる印象面の差 異を測定するうえで, 他のホログラム干涉 ${ }^{15)}$, モア レ縞 ${ }^{14)}$ やスペックル16)などを用いた非接触計測法 に劣らない高い測定精度を維持しつつ, 深くえぐ れた面を安定に測定することができ，さらに対象 物の色による影響が少ないのが特徵である。

本研究で用いたシステムは, この三次元微小変 形測定装置の利点を活かし, さらに結果の分析能 力を高めるために微小変形形状と対象物の絶対形 状とを測定できるよう改良したものである。具体 的には, 従来のシステムにカメラを一台追加し,
両眼視法により三次元形状を取得するようにし た。一般に両眼視法では左右一対の画像データの 対応点を検出するのが困難であるといわれてい る ${ }^{13)}$ が, 本システムでは, 対象物に対してランダム な縞模様を投影移動させたときの対象物上の経時 的な光強度の変化を測定し，その得られた光強度 の経時的波形が左右で一致する点を検索すること で左右の画像の対応点を検出している。このとき システムの測定精度は, 固定された左右のカメラ と対象物との位置関係以外に, プロジェクタの移 動等の精度に直接影響されない。

本システムは対象物の絶対量と比較対象物の相 対誤差量とを測定する装置である。それぞれの測 定に際しては，投影する縞パターンを変更する以 外は同一の装置を用いるために，カメラと対象物 の位置関係を変更することなく実体量と微小変形 量を高い精度で測定できる。さらに非常に短時間 での測定が可能となったため，採得した印象面を 直接測定するに当たっての印象材の経時的な変形 はあまり問題にする必要はなくなった。

(2) 測定精度の検討

計測システムの測定精度を評価するための基礎 的実験を行ったが，実体計測については，カメラ の光軸方向の対象物の変化に対して $0.1 \mathrm{~mm} の$ 範囲で測定結果が収束し, 形状も正確に再現され, これは顎堤粘膜の形状を再現するには十分は精度 と判断された。

また微小変形計測については，対象物に微小変 形を加えたとき，どの測定結果においても \pm 10 $\mu \mathrm{m}$ の測定精度が得られることがわかった。これ らの結果は, 耿らの三次元微小変形計測装置に CCD カメラの補正抢よび縞パターンの改良を加 えたためと考えられる。

さらに顎堤粘膜のように予測し難い自由変形を 起こす物体の測定の場合の精度検定も行ったが, 満足な結果が得られた。つまり，ゴム球の変形に ついて微小変形計測の結果をもとに描いた三次元 透視図から変形前後の相対的な変形量はある程度 わかるものの, 変形後に対象物がどのような形状 になったのかを正確に判断するのは困難であっ 
た。それに対して，微小変形計測と実体計測の測 定結果を併せた変形前後の三次元透視図を描くこ とにより，ゴム球の中央付近がくぼむように変形 していることが容易に理解できるようになった。 つまり，本システムで新たに加えた実体計測によ り微小変形計測のみの欠点が補われ，ミクロ的に もマクロ的にも変形の様相が正確に捉えられるよ うになった。

\section{2 ) 被験者}

被験者はいずれも義歯装着者で, 現在使用して いる義歯は日常生活をする上で特に問題はなく, 欠損部顎堤は極度の吸収がなくほぼ標準的な形態 を呈し，粘膜面には義歯による著しい圧痕は認め られなかった。

3 ) 粘膜面印象用トレー

本実験では，欠損部顎堤の印象面形態のみを比 較するため，印象用トレーは欠損部顎堤のみを印 象採得するものとした。このトレーは顎堤部に適 合するレジン部が可撤性で，ねじにより 3 点で金 属部に固定される。トレーは, 辺縁の位置を臨床 で用いられる筋圧形成後の個人トレーと同様にす る必要があるため, あらかじめ個人トレーを用い てポリサルファイドラバー印象材により機能印象 を行った模型より製作した。加圧印象を想定した ものについては,トレーには空隙を設けなかった。 これに対するコントロールでは空隙の量を 1.4 $\mathrm{mm}$ とし, 粘膜に印象採得時の圧があまりかから ない状態を設定した。また，辺緑の筋圧形成の有 用性を検討するために辺縁の短いトレーも用意し た。松元 ${ }^{4)}$ は，コンパウンドの変形や破折を考慮す ると筋圧形成の必要な部分のコンパウンドの量は $3 \mathrm{~mm}$ 程度でよいと述べていることから, 辺縁の 短いトレーは筋圧形成後の加圧印象を想定したト レーより辺縁を $3 \mathrm{~mm}$ 短く設定した。

4 ）印象用トレーの圧接条件

実際の臨床では，印象採得の際にトレーを口腔 内で所定の位置まで圧接し，そのままトレーを保 持する必要がある。星野7は口腔内でのトレーの 圧接速度を測定し, 平均 $118.0 \mathrm{~mm} / \mathrm{min}$ であった と述べている。また松元 ${ }^{2}$ は口腔内でのトレーの

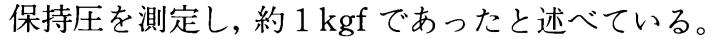
そこで本実験では，印象用トレ一の挿入方向規定 用のガイドレールの長さが約 $7 \mathrm{~mm}$ であること から，トレーの挿入時間を約 3 秒に規定し，速度 も可及的に一定になるように保ちながら手指にて 挿入した。挿入後は保持装置を用いて，印象採得 を行う久損側の犬歯上で手指による圧が $1 \mathrm{kgf}$ と なるようモニタリングしながら保持した。

5 ) 形状計測

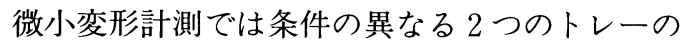
印象面の相対誤差を計測する。そのためにはカメ ラの前では, 比較すべき 2 種類の印象面を口腔内 の位置関係に正確に再現して固定する必要があ る。そこで本研究では形状計測用のジグを製作し た。このジグには印象用トレーの金属部を直接固 定することができ，これにより CCD カメラと金 属部の位置関係が固定される。そのため形状計測 の際の操作は印象用トレーのレジン部を金属部と 着脱するだけとなり, CCD カメラに対するトレー の位置再現精度もレジン部と金属部と間の着脱精 度のみで決まることとなる。ジグの位置再現精度 は, 平均 $0.988 \mu \mathrm{m}$ で標準偏差は $1.309 \mu \mathrm{m}$ で あった。これは特殊な方法を用いず比較的簡便な 方法で製作したにも関わらず，従来の三次元的位 置再現法 ${ }^{5,26)}$ と比べて高い再現精度となった。

形状計測で得られた結果から印象面全体の加圧 状況を把握するために, 実体量と微小変形量につ いて三次元透視図を作成した。またこれらのデー 夕をもとに煩舌的な断面図も作成したが，断面の 部位については, 測定領域のうちで煩棚の最も幅 がある部位，すなわち測定領域の中央部とした。

\section{2. 研究結果}

1) 印象材のフローが一定でトレーの空隙があ る場合とない場合の印象面形態

印象用トレーの空隙の量を変化させた場合の顎 堤の形状を検討したものに, 平井 ${ }^{9)}$, 田中 ${ }^{10)}$,

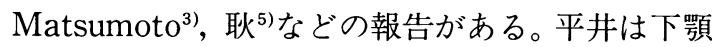
片側臼歯部欠損の顎堤粘膜形状を測定し, 顎堤頂 部は頓舌側部に比較して変位量が小さかったと述 べている。これに対して田中も同様の顎堤粘膜の 
形状を測定しているが，顎堤頂部は煩舌側部に比 較して変位量が大きかったと述べている。Matsumotoはシミュレーションモデル上で個人ト レーを用いた実験で，顎堤頂部での変形が最も大 きく $0.31 \mathrm{~mm}$ であったと述べている。また耿は 煩側部の変位量が最大であったと述べている。

本研究では，空隙があるトレーより空隙のない トレーを用いた場合のほうが粘膜が大きく変位し たが, 部位別には顎堤頂付近よりも煩, 舌側とも 辺縁部のほうが変位の程度が強く, 特に辺縁に近 づくに従って変位量が大きくなっていた。これは, 田中の報告と一致していた。また舌側については, 空陌のあるトレーより空隙のないトレーを用いた ほうが大きく変位する傾向はあったものの, 量や 部位による特徵的な傾向がみられなかった。これ は印象採得時の被験者の嚥下や舌の移動に伴い, トレーの下にある舌側の顎堤粘膜がトレ一印象面 を圧迫したことによるものと考えられる。

レギュラータイプおよびインジェクションタイ プについて，トレーの空隙の有無による印象面へ の影響を比較すると，辺縁付近ではレギュラータ イプよクインジェクションタイプを用いたときの ほうが空隙による影響を受けやすかった。これは， 辺縁付近ではレギュラータイプよりインジェク ションタイプのほうが印象材による粘膜の変位が 少なく，印象面形態はトレ一の内面の形状に影響 を受けているためと考えられる。

2）トレーの空隙の条件が一定で印象材のフ ローを変化させた場合の印象面形態

印象材のフローを変化させたときの印象面形態 は，トレーの空隚の有無に関係なく，頓側辺縁で レギュラータイプのほうが大きく変位していた。 これはフローの悪い印象材のほうがフローのよい 印象材よりも粘膜の変位量が大きくなり, トレー の条件が同じ場合には変位量は印象材のフローに 依存することが考えれる。レギュラータイプの場 合とインジェクションタイプの場合との粘膜の変 位量の差が空隙のないトレーの場合には 300 500 $\mu \mathrm{m}$ の間に収束したのに対し，空隙のあ るトレーでは 250 980 $\mu \mathrm{m}$ と分布幅が大きく
なったのは，空隙のあるトレーのほうが印象材の 絶対的な厚みが大きく，トレー内での印象材の流 れが空隙のないトレーよりも複雑になったと考え られる。そのために被験者の顎堤の形態やトレー をとりまく筋などの影響によって被験者間で変位 量に大きな開きが生じたと考えられる。顎堤頂付 近でインジェクションタイプがレギュラータイプ より変位しているのは，インジェクションタイプ の流出が頓側辺縁において粘膜により妨げられた 際に，トレー内で対流したために顎堤頂付近で大 きく変位する傾向が現れたと考之られる。

平井 ${ }^{9}$ は強密接様式のトレーと弱密接様式のト レーにより，異なる印象材を用いて顎堤粘膜の形 状を計測しており, 弱密接様式のトレーの場合顎 堤粘膜の加圧量は印象材の性状に支配されている が，強密接様式のトレーでは印象材の性状による 変位量の差はほとんどなかったと述べている。本 研究では，空隙のないトレーを用いたとき，すな わち平井の研究での強密接様式のトレーの場合, 顎堤頂付近での粘膜の変位量は $100 \mu \mathrm{m}$ 以下と印 象材の性状による影響は少ないと考えられるもの の，辺縁付近では印象材の性状による影響は大き くフローの悪い印象材のほうが大きく変位する傾 向があった。空隙のあるトレーでは, 平井が述べ ているようには粘膜の変位の状態は単純に印象材 の性状に支配されてはいなかった。これは，平井 が用いている印象用トレーは既製トレーを用いて いるのに対し, 本研究では筋圧形成したトレーに 空隙を与えたものであり, 粘膜を変位させる要素 として印象材だけでなくトレーの内面の形態も関 与していることにより結果に差異が生じたと考え られる。

3 ) 印象材のフローとトレーのスペーサの量が 一定でトレ一の大きさを変化させたときの印 象面形態

粘膜負担の大きい部分床義歯では, 義歯床の咬 合圧負担能力の増大を図り義歯の安定と支持を獲 得するために，義歯床を可及的に大きく設定する ことが必要である。この状態を印象面に印記する ためには，印象採得時にトレー辺緑を筋圧形成を 
し, 辺縁部での印象材の流出を防止することで床 下粘膜の加圧印象が得られるといわれてい $3^{1,23,24)}$ 。

印象用トレーの辺縁の長さを変化させたときの 印象面形態を検討してみると，レギュラータイプ を用いた場合，4 人中 3 人で辺縁の短いトレーよ り辺緑の長いトレーの方が大きく変位する傾向が 認められ，顎堤頂付近を最小に辺縁部で最大にな るように変位していた。また顎堤頂付近で辺縁の 短いトレーのほうが辺縁の長いトレーより変位す る傾向にある場合でも辺縁付近では長いトレーの ほうが変位する傾向にあった。このように，辺縁 付近での変位の傾向については，特に頓舌的断面 の結果からわかるようにトレーの辺縁の位置の相 違が印象面形態に直接影響しており，これは印象 材の流れによる変位というよりもむしろトレ一辺 縁の形態そのものに変位量の差が依存していると 考えられる。

インジェクションタイプを用いた場合，辺縁付 近では辺縁の長いトレーのほうが短いトレーより 大きく変位する傾向が認められた。顎堤頂付近で は狭い範囲で 4 人中 3 人が辺縁の短いトレーのほ うが長いトレーより大きく変位する傾向があった が，それ以外の部位では辺縁の長いトレーのほう が短いトレーより大きく変位する傾向にあった。 辺縁での変位についてはレギュラータイプの印象 材を用いたときと同様に，印象材による変位量の 差というより印象用トレーの辺縁の形態に影響さ れていると考えられる。

以上より, 印象条件の相違により欠損部顎堤粘 膜は種々の変位を示すことが確認されたが，印象 面形態を決定する因子にはトレーの圧接速度，卜 レーの加圧部位，加圧方向など他にも多く考えら れこれらとのかかわり合いについてもさらなる 検討が必要であると考えられる。

\section{VII. 結 論}

部分床義歯の印象採得条件の相違が, 欠損部顎 堤粘膜の形態に及ぼす影響を検討する目的で，新 たに非接触方式によるステレオ型時空間微分三次
元計測システムを開発した。下顎の Kennedy 1 級あるいは 2 級の欠損様式を有する被験者につい て, 印象用トレーの空隙量, 使用する印象材のフ ローならびにトレーの大きさの違いをパラメータ として印象採得を行い，その印象面について本シ ステムで形状計測を行った結果, 以下の結論を得 た。

\section{1. 計測システムの精度評価}

1) 実体計測については，既知の大きさを有す る対象物を測定した結果, $10 \mathrm{~mm}$ 程度の大きさの 物体に対しては, $\pm 0.1 \mathrm{~mm}$ の誤差で測定可能で あることがわかった。これは粘膜印象面の形状を 測定するうえでは十分な精度であると考えられ る。

2 ) 微小変形計測については, 既知の微小変形 量を与之た測定の結果, 変形量が $1 \mathrm{~mm}$ 程度であ れば $\pm 10 \mu \mathrm{m}$ の誤差で測定可能であった。これは 顎堤の変形量を計測するには十分な精度であると 考えられる。

3 ）実体計測と微小変形計測を併用した場合, 予測のつかない変形に対しても変形の様相を正確 に把握することが可能であることがわかった。

\section{2. 印象採得条件の違いが欠損部額堤粘膜の印象 面形態に及ぼす影響について}

1）空陌のあるトレーより空陌のないトレーの ほうが粘膜の変位が大きくなる傾向にあり，これ は顎堤頂を最小に煩側辺縁付近で最大となった。 舌側では粘膜が変位したが一定の傾向はみられな かった。

2 ）印象材のフローの違いについては, 煩側辺 縁付近と舌側辺縁付近ではレギュラータイプのほ うがインジェクションタイプより大きく変位し た。顎堤頂付近ではインジェクションタイプのほ うがレギュラータイプより変位していることが多 かった。

3）辺縁の長い印象トレーを用いたほうが短い トレーの場合と比較して辺縁付近がより大きく変 位する傾向がみられた。 


\section{謝 辞}

稿を終えるに臨み，ご懇篤なるご指導とご校閲を賜 りました藍稔教授に謹んで感謝の意を表します。 さらに，終始䭒切なるご指導とご教示をいただきまし た歯科補経学第一講座, 岡部良博講師と山下秀一郎助 手に心からお礼申し上げます。また，終始格別のご指 導, ご教授をいただきました東京大学工学部計測工学 科, 安藤 繁助教授と東京農工大学工学部電子情報工 学科, 篠田裕之講師に心から感謝いたします。ならび に，本研究に際し，ご援助，ご協力いただきました歯 科補緅学第一講座の諸先生方, ならびに被験者の方々 に心よりお礼申し上げます。

本研究の要旨の一部は, 平成 6 年 11 月, 第 92 回日 本補緅歯科学会学術大会において発表した。

\section{文献}

1）藍 稔：小部分床義歯学. 東京, 1986, 学建書 院，132-135.

2）松元 誠：遊離端義歯. 東京, 1980 , 医歯薬出版, 151-164.

3) Matsumoto, M.: An experimental imvestigation for analyzing the infuence of impression procedures in clinical technique. The Bull of Tokyo Medical Dent Univ. 17 : 345-356, 1970.

4）松元 誠：部分床義歯の印象法. DE 22：111,1972 .

5）耿 啓還：部分床義歯における印象採得条件の 相違が欠損部顎堤粘膜の微小形態変化に及ぼす 影響について。病誌 $60: 35-53 ， 1993$

6) 関根 弘, 田島篤治, 海洲馨一, 溝上隆男, 岡田 京子, 平井泰征, 前田佳英 : 有床義歯のための印 象方法に関する基礎的ならびに臨床的研究 第 3 報 粘弾性を有する被印象体の印象時におけ る変位状態について. 歯科学報 $71 ： 2167-2172$.

7）星野 亨：印象採得法の基礎的検討 第 2 報 レーのスペーサとベントについて. 補緅誌 26 ： 322-340, 1984.

8）古宇田 昌：印象法が遊離端義歯の適合性に及 ぼす影響について。補緅誌 25：142-153，1981。

9）平井泰征：有床義歯における印象時の粘膜の被 圧状態が印象面形態に及ぼす影響に関する実験 的研究. 歯科学報 $71: 1835-1869,1971$.

10）田中 淳：印象圧の相違が顎粘膜形態および義 歯の適合性に及ぼす影響に関する研究. 補経誌 $26: 455-471,1982$.

11）松津雅道：印象採得法の相違が顎粘膜形態およ び義歯の適合性に及ぼす影響に関する研究下
顎片側遊離端欠損症例について。補緅誌 28 ： 341-357, 1984.

12）篠田裕之, 耿 啓還, 山下秀一郎, 藍 稔, 安 藤 繁：口腔粘膜の変形測定とその微分型立体 計測システム。計測自動制御学会論文集 29： 963-972, 1993.

13）尾上守夫：画像処理ハンドブック．東京，1987, 昭晃堂, 392-407.

14) Meadows, D. M. : Generation of surface contours by moire patterns. Appl. Opt. 9 : 942-947, 1970.

15) Haines, K. and Hildebrand, B. P. : Counter generation by wavefront reconstruction. Phys. Letters. $19: 10-11,1965$.

16) Dainty, J. C. : Laser speckle and related phenomena. Topics in Applied Physics 9 : 203-253, 1984.

17）安藤 繁：微分両眼立体視法による多層立体知 覚の基礎. 計測自動制御学会論文集 24 ： 973-979, 1988.

18) Holmes, J. B. : Influence of impression procedures and occlusal loading on partial denture movement. J. Prosthet. Dent. 15 : 474-481, 1965.

19) Watt, D. M., Macgregor, A. R., Geddes, M., Cockbubn, A. and Boyd, J. L. : A preliminary investsigation of the support of partialdentures and its relationship to vertical loads. Dental Practitioner 9:2-15, 1958.

20) Leupold, R. J. : A comparative study of impression procedures for distal extension removable partial denture. J. Prosthet. Dent. 16 : 708-720, 1966.

21) Leupold, R. J., Flinton, R. J. and Pfeifer, D. L. : Comparrison of vertical movement occurring during loading distal-extension removable partial denture bases made by three impression technique. J. Prosthet. Dent. 68 : 290-293, 1992.

22) Vahidi, F.: Vertical displacement of distalextension ridges by different impression techniques. J. Prosthet. Dent. 40 : 374-377, 1978.

23）大沢一博：下顎有床義歯における臼歯部舌側床 縁の条件が義歯の維持に及ぼす影響に関する研 究. 歯科学報 $74: 1511-1553,1974$.

24）大澤 勤：下顎義歯における煩側床縁の設定基 準に関する実験的研究. 歯科学報 79:20352083, 1979.

25）星野 亨, 潤米宏仁, 久保田幸生, 泉田一蔵, 田 島直孝, 山田博明, 山本克之, 祇園白信仁, 森谷 良彦: 印象採得法の基礎的検討 第 1 報 シ ミュレーションモデルと三次元的位置再現装置 について。補緅誌 27：759-766，1983. 